\title{
COLLABORATIVE ROBOTICS: A LITERATURE OVERVIEW FROM THE PERSPECTIVE OF PRODUCTION MANAGEMENT
}

\author{
Juliano Endrigo Sordan (https://orcid.org/0000-0002-2188-9051) ${ }^{1^{*}}$ \\ Marcio Lopes Pimenta (https://orcid.org/0000-0003-3899-3274) ${ }^{2}$ \\ Pedro Carlos Oprime (https://orcid.org/0000-0002-6213-2223) ${ }^{1}$ \\ Yasmine Tomasella Rodrigues (https://orcid.org/0000-0001-5596-8295) ${ }^{3}$ \\ Clesio Aparecido Marinho (https://orcid.org/0000-0002-6839-5251) ${ }^{1}$
}

1 Federal University of São Carlos, 13565-905, São Carlos-SP, Brazil

2 Federal University of Uberlândia, 38408-100, Uberlândia-MG, Brazil

3 University of São Paulo, 14040-905, Ribeirão Preto-SP, Brazil

\section{*julianosordan@yahoo.com.br}

\section{Submitted: 23/02/2021. Accepted: 16/04/2021}

Published: 17/04/2021

\begin{abstract}
Purpose: This paper aims to understand the specificities inherent to collaborative robotics from the perspective of production and operations management, as well as to identify opportunities for future research on the topic.
\end{abstract}

Methodology/Approach: A systematic literature review was carried out through Scopus and Web of Science databases. This procedure covered 84 articles published between 1997 and 2018.

Findings: The study revealed the issues most addressed in the research on Collaborative robots (Cobots), the most cited works, and the research approaches adopted.

Research Limitation/implication: The sample was extracted from only two international databases excluding publications in the form of books and articles from other databases.

Originality/Value of paper: The study reveals some specificities regarding the application and development of COBOTs, as well as their advantages and drawbacks in the scope of production management.

KEYWORD: collaborative robotics, cobot, industry 4.0, systematic literature review.

\section{ROBÓTICA COLABORATIVA: UM PANORAMA DA LITERATURA À LUZ DA GESTÃo DA PRODUÇÃO RESUMO}

Objetivo: Este artigo tem como objetivo compreender as especificidades da robótica colaborativa sob a perspectiva da gestão da produção e operações, assim como identificar oportunidades para pesquisas futuras sobre o tema.

Metodologia/Abordagem: Foi conduzida uma revisão sistemática de literatura nas bases de dados Scopus e Web of Science. Esse procedimento envolveu 84 artigos publicados entre 1997 e 2018.

Conclusões: A análise do referencial teórico revelou os assuntos mais abordados na pesquisa dedicada aos robôs colaborativos (Cobots), os trabalhos mais citados e as abordagens de pesquisa adotadas.

Limitações da pesquisa: A amostra foi extraída de apenas duas bases de dados internacionais excluindo publicações na forma de livros e artigos disponibilizados em outras bases de dados.

Originalidade/Valor do artigo: O estudo apresenta algumas especificidades a respeito da aplicação e desenvolvimento dos COBOTs, assim como suas vantagens e restrições no âmbito da gestão da produção.

PALAVRAS-CHAVE: robótica colaborativa, cobot, indústria 4.0, revisão sistemática de literatura. 


\section{INTRODUCTION}

The paradigm of the fourth industrial revolution, also known as "Industry 4.0" (i4.0), represents an important challenge for organizations that aim to convert their current manufacturing processes to the digital manufacturing model, to obtain competitive advantages through technological updating (Wang; Wang, 2016; Pimenta, 2019). In this scenario, new opportunities and challenges arise in manufacturing management by enabling the use and integration of technologies such as Industrial Internet of Things (IIoT), simulation, advanced robotics, cloud computing, additive manufacturing, and augmented reality (Rüßmann et al., 2015; Tamás et al., 2016; Schwab, 2017). In this context, an industrial robot will work collaboratively with operators, acting as an auxiliary resource to perform a specific task.

Although the application of robotics in manufacturing processes is an inherent characteristic of the third Industrial Revolution, the new productive paradigm proposes to optimize this type of technology through the evolution of traditional robots to intelligent robots, capable of learning and collaborating with human beings (Rüßmann et al., 2015). Therefore, autonomous industrial robots are being developed to increase safety, flexibility, versatility, and collaboration on the shop floor without isolating a work area (Bahrin et al., 2016). Other technologies associated with the new industrial paradigm, including artificial intelligence, the Internet of Things (IoT), cloud computing, and Big Data will change robots' application in industrial processes in the coming years (RoblaGómez et al., 2017).

In addition to the aspects related to the productivity of the manufacturing processes, safety represents a crucial factor in implementing industrial robotics. The publication of the technical specification ISO / TS 15066: 2016 (ISO, 2016) aims to update international safety standards for adopting Collaborative Robots (COBOTs), detailing the project requirements and risk assessment and their major impacts on specific parts of the human body. Considering that industrial robots can be large, heavy, and move at high speeds, the implementation of this technology must avoid potential impacts between the robot and a human within an automated workstation (Hedelind and Jackson, 2011). In this context, it is already possible to highlight some solutions aimed at work safety, including mechanical reliability systems, lightweight structures, contact detection devices, artificial vision systems, among others (Robla-Gómez et al., 2017).

The research on collaborative robotics can be justified due to safety reasons to reduce operator injuries during production and the need for faster production and economic gains (Bayram and Ince, 2018). Thus, considering the relevance of the theme for the improvement of industrial processes, the following Research Questions arise: (RQ1) "What are the specificities inherent to COBOTs?"; and (RQ2) "Which topics could be investigated in the future regarding collaborative robotics?". Thus, this article aims to understand the specifics of collaborative robotics from a systematic literature review based on articles published in the Scopus and Web of Science databases from 1997 to 2018.

This article is structured as follows: in section 2, the research procedures adopted in the study are presented; in section 3, the specifics on the theme are presented, as evidenced in the theoretical framework analyzed, as well as a brief descriptive analysis of the subjects covered; section 4 presents some opportunities for future research; and finally, in section 5 the final considerations are presented in detail.

\section{METHODOLOGICAL APPROACH}

In order to find answers to the research questions presented in the introduction to this article, the method adopted for the study was a systematic literature review, following the procedures presented by Silva et al. (2015). Such a research method provides a solid basis for future research 
and contributes to developing theories, aligns knowledge about existing research and discovers areas where potential studies are needed (Webster and Watson, 2002).

Figure 1 shows the procedure for Systematic Literature Review performed in this study. The first step was carried out in January 2019 and consisted of selecting the databases, horizontal scan and vertical scan, based on the study conducted by (Silva et al., 2015). We decided to select two databases (Scopus and Web of Science) widely recognized by the academic community, considering the relevance of the articles indexed in journals with an impact factor and the feasibility of access and stratification. The term "collaborative robot" was defined as the search string since most publications on these databases are available in the English language, and it encompasses the terms "cobots" and "collaborative robots." Thus, 551 articles were identified in the Scopus database and 148 articles in the Web of Science database.

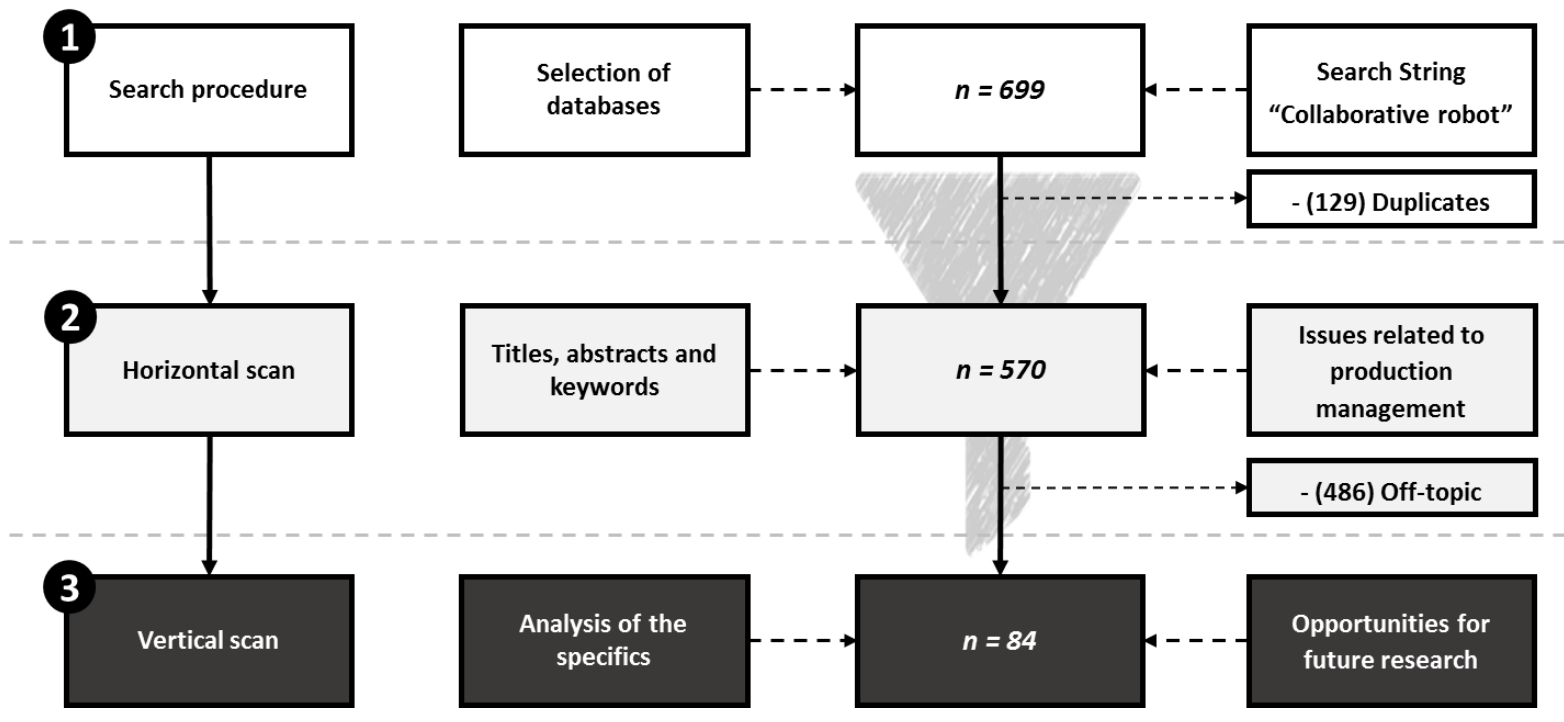

Fig. 1 - Procedure for Systematic Literature Review

After removing 129 duplicate articles, a second criterion was applied to filter the volume of publications (horizontal scan) by reading the elements: title, abstract and keywords. It is important to highlight that part of the works selected at this stage of the research highlighted only technical and operational aspects of COBOTs, including specifications, use of algorithms, and programming language, in addition to applications outside the context of manufacturing, such as civil engineering, teaching, medicine, among others. Thus, after removing 486 articles outside this study's scope, it was possible to conduct a content analysis (vertical scan) of the 84 selected articles published between 1997 and 2018.

\section{LITERATURE REVIEW}

\subsection{Initial analysis}

The initial analysis consisted of an observation of the subjects and topics in each article's titles and keywords, limited to five terms for each article. As an example, in the article "Legibility and Predictability of Robot Motion" (Dragan et al., 2013), three central themes were identified: (i) analysis of movements; (ii) trajectory planning; and (iii) gesture recognition. In order not to overload the list of subjects covered, several terms with the same connotation, i.e., "collaborative robots," "COBOTs," "collaborative work," and "human-machine interaction," were excluded from the list of themes. Besides, the terms related to the research methods used in the studies were also 
disregarded, as they will be discussed later. Thus, the most expressive issues observed in more than one article were classified in frequency observed and presented in Table 1.

Table 1: Main issues addressed

\begin{tabular}{lcclcc}
\hline \multicolumn{1}{c}{ Issues } & Article (s) & $\boldsymbol{\%}$ & Issues & Article (s) & $\%$ \\
\hline Safety & 18 & 21.43 & Ergonomics & 3 & 3.57 \\
\hline Assembly line & 17 & 20.24 & Algorithms & 2 & 2.38 \\
\hline Sensing & 11 & 13.10 & Gripper systems & 2 & 2.38 \\
\hline Motion analysis & 11 & 13.10 & Handling systems & 2 & 2.38 \\
\hline Risk analysis & 8 & 9.52 & Teamwork & 2 & 2.38 \\
\hline Architecture & 7 & 8.33 & Standardization & 2 & 2.38 \\
\hline Kinematics & 6 & 7.14 & Industry 4.0 & 2 & 2.38 \\
\hline Industrial automation & 6 & 7.14 & Cyber-physical systems & 2 & 2.38 \\
\hline Baxter Robot & 5 & 5.95 & Smart Factory & 2 & 2.38 \\
\hline Mobility & 5 & 5.95 & Desktop & 2 & 2.38 \\
\hline Learning systems & 4 & 4.76 & ISO 10218 & 2 & 2.38 \\
\hline Path planning & 4 & 4.76 & Multi-agent system & 2 & 2.38 \\
\hline Visual systems & 4 & 4.76 & Fuzzy System & 2 & 2.38 \\
\hline Gesture recognition & 3 & 3.57 & Robustness & 2 & 2.38 \\
\hline Social aspects of robotics & 3 & 3.57 & Object detection & 2 & 2.38 \\
\hline Framework & 3 & 3.57 & Virtual reality & 2 & 2.38 \\
\hline Manipulating robot & 3 & 3.57 & Machine design & 2 & 2.38 \\
\hline
\end{tabular}

We noticed that the five most addressed issues, when added up, represent $77.38 \%$ of the publications and portray topics related to the health and safety of the work environment, applications in assembly lines, and technical aspects of the COBOTs, including motion analysis, kinematics, and sensing systems. However, considering the aspects of production and operations management, eight of the thirty-four issues are directly related to occupational safety and health (safety, risk analysis, gesture recognition, social aspects of robotics, ergonomics, work in team, work environment, and ISO 10218). Still, three of them are connected to the recent paradigm of the fourth Industrial Revolution (i4.0, Cyber-physical Systems, and Smart Factory).

Regarding the security of collaborative environments, we noticed that the studies address aspects related to the operation of COBOTs, such as working speed, proximity to operators in order to avoid collisions, recognition between operators and materials, and monitoring the distance between operators (Šurdilović et al., 2003; Matthias et al., 2011; Aaltonen et al., 2018). Among the issues highlighted above, only one refers to the type of commercial solution for COBOTs. The 'Baxter robot,' occupying the ninth position in Table 1, is a robot developed by Rethink Robotics, equipped with two arms and a screen that performs the function of a face so that the operator can communicate with the robot and that shows when yourself is learning or performing an operation. Also, Baxter robots are equipped with a software platform that allows them to carry out a sequence of complex tasks, such as handling a component and instructing an "approved" or "approved" type inspection station to the stacking of materials (Briody, 2013).

Another relevant characteristic of the state-of-the-art on collaborative robotics concerns the studies' methodological and scientific focus around the theme. In this sense, Table 2 shows a distribution of the publications observed concerning the research approach. Such distribution was stratified in four periods, with greater amplitude attributed to the first two periods, considering that the theme gained greater relevance from the concepts of advanced robotics and i4.0, both disseminated from 2011 and, therefore, with a highest expected frequency. 
Table 2: Research approaches

\begin{tabular}{|c|c|c|c|c|c|c|c|}
\hline \multirow[b]{2}{*}{ Period } & \multirow[b]{2}{*}{ No. } & \multirow[b]{2}{*}{$\%$} & \multicolumn{5}{|c|}{ Research Approach } \\
\hline & & & Modeling & Experiment & Simulation & $\begin{array}{c}\text { Theoretical } \\
\text { Study }\end{array}$ & Case study \\
\hline $1997-2003$ & 3 & 3.57 & 0 & 1 & 1 & 1 & 0 \\
\hline 2004-2010 & 10 & 11.90 & 0 & 5 & 1 & 4 & 0 \\
\hline 2011-2014 & 12 & 14.29 & 1 & 7 & 0 & 3 & 1 \\
\hline $2015-2018$ & 59 & 70.24 & 2 & 28 & 4 & 11 & 14 \\
\hline Total & 84 & 100 & 3 & 41 & 6 & 19 & 15 \\
\hline
\end{tabular}

Many articles that address COBOTs as the central theme used experiments as the major research approach. Such studies represent $48.81 \%$ of all recovered publications. Theoretical and empirical studies (case studies) also stand out, representing $40.48 \%$. It is important to note that the articles published between 2011 and 2018 correspond to $84.53 \%$ of the sample. These papers reveal the contemporaneity of the theme alongside the technologies associated with i4.0. In order to provide a ranking of the most prolific and cited articles, we developed Table 3 informing the authorship, the number of citations reported in the databases, the research approach and a synthesis of the contributions of these works.

\subsection{Specificities inherent to Cobots}

One way to understand the specifics regarding manufacturing processes' specifics is to find answers to four questions that can differentiate one technology from another (Slack et al., 1999). These questions include: (Q1) What does technology do?; (Q2) How does it develop?; (Q3) What advantages does this technology offer?; and (Q4) What restrictions does the technology bring to the production? Thus, these four questions were used to understand the specificities inherent to collaborative robotics to find answers to the first research question previously presented in the introduction section.

Regarding the application of COBOTs, or in other words, what they are capable of, the literature shows that industrial robotics is recommended for environments where human beings are exposed to activities with significant risk and where efficiency is greater when compared with the tasks performed by humans (Gunasekaran, 1999; Hedelind and Jackson, 2011; Lasota and Shah, 2015). Industrial robots are traditionally directed to activities called 3D's, that is, dirty, dangerous, and dull (Murphy et al., 2000; Bloem et al., 2014). Therefore, industrial robotics can be used in a variety of sectors, such as automotive and aerospace, medical, consumer goods, and electronics, among others, with the most common applications covering welding, testing, labeling, drilling, cutting activities, painting, molding, removal, and movement of materials (Thomopoulos, 2014).

COBOTs, in turn, are industrial robots specifically designed to perform a variety of repetitive and non-ergonomic tasks and cooperate directly and safely with operators, being able to use force and collision detection capabilities (Romero et al., 2016). Portability is a key feature of this technology type since the operator must program these robots' operations in a simple way and safely (Djuric and Urbanic, 2018). It is important to note that an industrial robot is a reprogrammable automatic manipulator capable of handling objects with varying degrees of freedom through programmed movements to perform a variety of tasks (Slack et al., 1999). In this sense, the operationalization of COBOTs requires a workplace design adapted to this technology, 
selecting a control system, and creating a control program using algorithms related to kinematic tasks (Sapietová et al., 2018).

Table 3: Top 10 articles

\begin{tabular}{|c|c|c|c|c|}
\hline Rank & $\begin{array}{c}\text { Author (s) / } \\
\text { Year }\end{array}$ & $\begin{array}{l}\text { No. of } \\
\text { Citations }\end{array}$ & $\begin{array}{l}\text { Research } \\
\text { Approach }\end{array}$ & Contribution \\
\hline 1 & $\begin{array}{l}\text { Peshkin et al. } \\
\quad(2001)\end{array}$ & 178 & $\begin{array}{l}\text { Theoretical } \\
\text { Study }\end{array}$ & $\begin{array}{l}\text { Explanation of the kinematics and operational aspects of the } \\
\text { transmission between conventionally operated COBOTs } \\
\text { versus non-holonomic COBOTs used in the car assembly } \\
\text { process. }\end{array}$ \\
\hline 2 & $\begin{array}{l}\text { Dragan et al. } \\
\quad(2013)\end{array}$ & 120 & Experiment & $\begin{array}{l}\text { The results showed that the predictability and readability of } \\
\text { COBOTs are fundamentally different and often contradictory } \\
\text { properties of movement. }\end{array}$ \\
\hline 3 & $\begin{array}{c}\text { Roy and } \\
\text { Dudek (2001) }\end{array}$ & 83 & Simulation & $\begin{array}{l}\text { The article presents an algorithmic solution for } \\
\text { communication between agents over long distances, allowing } \\
\text { two robots to meet in order to explore an unknown } \\
\text { environment collaboratively. }\end{array}$ \\
\hline 4 & $\begin{array}{l}\text { Andersson and } \\
\text { Nygards } \\
(2008)\end{array}$ & 49 & Simulation & $\begin{array}{l}\text { The authors propose an algorithm to align and join maps and } \\
\text { trajectories in a multi-robot system. The trajectory } \\
\text { information can be reused to verify a possible path in an } \\
\text { unknown region. }\end{array}$ \\
\hline 5 & $\begin{array}{l}\text { Merchán-Cruz } \\
\text { and Morris } \\
\text { (2006) }\end{array}$ & 41 & Simulation & $\begin{array}{l}\text { The study provides a fuzzy genetic algorithm to address two } \\
\text { manipulating robots' trajectory planning problems, sharing a } \\
\text { common workspace whose trajectory or behavior is } \\
\text { unknown and unpredictable. }\end{array}$ \\
\hline 6 & $\begin{array}{l}\text { Krüger et al. } \\
\quad(2006)\end{array}$ & 39 & Experiment & $\begin{array}{l}\text { It proposes a system of workspace shared between COBOTs } \\
\text { and operators through direct physical contact. The path } \\
\text { guidance and power amplification functions can be } \\
\text { performed by this system. }\end{array}$ \\
\hline 7 & $\begin{array}{l}\text { Šurdilović } \\
\text { et al. (2003) }\end{array}$ & 36 & Experiment & $\begin{array}{l}\text { The article presented a new system for COBOTs with } \\
\text { continuous variable transmission. Basic structures, kinematic } \\
\text { and dynamic models, as well as control algorithms were also } \\
\text { briefly presented in this study. }\end{array}$ \\
\hline 8 & $\begin{array}{l}\text { Matthias et al. } \\
\quad(2011)\end{array}$ & 32 & $\begin{array}{l}\text { Theoretical } \\
\text { Study }\end{array}$ & $\begin{array}{l}\text { This study discusses the safety certification process for } \\
\text { industrial collaborative robotics, using procedures for risk } \\
\text { assessment. They also analyzed the possible contact events } \\
\text { between a robot and a human being. }\end{array}$ \\
\hline 9 & $\begin{array}{l}\text { Rozo et al. } \\
(2016)\end{array}$ & 30 & Experiment & $\begin{array}{l}\text { The authors present a framework for an operator to teach } \\
\text { COBOTs from demos, combining probabilistic learning, } \\
\text { dynamic systems, and stiffness estimates to encode the } \\
\text { robot's behavior throughout the task. }\end{array}$ \\
\hline 10 & $\begin{array}{l}\text { Romero et al. } \\
\text { (2016) }\end{array}$ & 29 & $\begin{array}{l}\text { Theoretical } \\
\text { Study }\end{array}$ & $\begin{array}{l}\text { The article presented the concept 'Operator } 4.0 \text { ', understood } \\
\text { as an intelligent and skilled operator who performs } \\
\text { cooperative work with robots through Cyber-physical } \\
\text { systems to achieve man-machine symbiosis in work systems. }\end{array}$ \\
\hline
\end{tabular}

The main advantage inherent in COBOTs is that this technology allows robots to collaborate with humans in a shared workspace to perform productive activities with greater productivity and efficiency (Lasota and Shah, 2015). Besides, COBOTs can also be an alternative resource to conventional material handling devices, such as articulated arms, elevators, winches, etc., since these resources presented ergonomic problems, generating operator fatigue, stress, and musculoskeletal disorders (Šurdilović et al., 2003; Krüger et al., 2006). 
A critical constraint associated with COBOTs concerns the necessary safety in the work environment, where the operator is directly exposed to contact with robots. The safety rules associated with COBOTs include technical aspects of the mechanical design for the manipulator and control measures for the robot's safe operation. These rules aim to eliminate the risk of injury to the human operator, such as impact force exerted on the operator, setting of fastening elements, and other hazards related to human-robot interaction (Matthias et al., 2011). In addition to safety issues, the implementation of COBOTs in the manufacturing process has some limitations that include (Krüger et al., 2006; Bayram and İnce, 2018):

- High technology acquisition and implementation costs.

- Restrictions and needs for adaptation in variable and unstructured environments.

- Complex programming, which may require qualified professionals.

- Shortcomings of collaborative work in the same workspace.

- Need to reconfigure robots to adapt to new activities.

- Problems related to workers' morale.

- Insufficient line availability.

- Nature of the productive activity that may require variable production and reduction.

\subsection{Opportunities for future research}

As previously presented, our second research question aims to understand which topics could be investigated in the future regarding collaborative robotics. Therefore, we analyze the primary suggestions and proposals for future research contained in the concluding sections of the selected papers. This information was grouped by affinities resulting in six central themes described below.

- Theme 1: Security. As the most expressive topic around the research on COBOTs, security is a subject with several possibilities for future studies. Matthias et al. (2011) suggested conducting analyses on the risk of injury, including the Failure Mode and Effects Analysis (FMEA) technique in contact situations based on simulations and determination of borderline values injury scale. Maurice et al. (2014) proposed the analysis of indicators to assess the ergonomic parameters inherent to collaborative robotics.

- Theme 2: Morale. In Table 1, we highlighted the issues "social aspects of robotics," "teamwork" and "work environment." Thus, it is possible to understand that operators' morale in environments shared by COBOTs deserves full attention in operational excellence projects that cover this type of technology. In this direction, Aaltonen et al. (2018) pointed out the need to develop metrics to assess the experience of collaboration and the workers' productivity when interacting with COBOTs.

- Theme 3: Standardization. Some specific norms for the standardization of collaborative robotics were evidenced in the literature. Future studies could investigate several aspects of these patterns, such as maturity levels, critical success factors, diagnoses, among others. The following standards were highlighted: ISO 10218: Safety requirements for industrial robots - Part 1: Robots, which establishes safety requirements and guidelines for the design of industrial robots and ISO 10218: Safety requirements for industrial robots - Part 2: Robot system and integration (Šurdilović et al., 2003; Virk et al., 2008; Matthias et al., 2011); ISO / TS 15066: Robots and Robotic devices, which provides guidelines for the implementation of a collaborative workspace; ISO / TC 184: Automation and Integration Systems, which provides requirements for industrial automation (Virk et al., 2008; Bogue, 2017); and ISO 13482: Robots and Robotic Devices, which provides safety requirements for operators working with robots (Bogue, 2017). 
- Theme 4: Comparative analysis of performance between different types of robots. The industrial robotics market encompasses several COBOT solutions provided by companies consolidated in the market, such as ABB (FRIDA), Rethink Robotics (Baxter), Universal Robots (UR10), Bosch (YuMi), among others. In this scenario, Cremer et al. (2016) suggested comparative studies between Baxter robots' performance with other robots regarding flexibility in arms control and trajectory planning.

- Theme 5: Integration of COBOTs with i4.0 technologies. With the improvement and integration of information technologies and industrial automation, new opportunities for the optimization of COBOTs appear in the context of digital manufacturing. The new configurations inherent to Cyber-physical Systems will require collaborative robots to be more efficient and able to interact with other technologies, such as remote communication using the Industrial Internet of Things - IIoT, cloud computing and cybersecurity (Brizzi et al., 2013; Bayram and İnce, 2018).

- Theme 6: Technologies applied to human-robot interaction. Future studies may aim to increase the communication efficiency inherent in the collaborative work between operators and robots. Barattini et al. (2012) suggested incorporating audio commands and expansion of gesture recognition techniques for the fingers. Lasota and Shah (2015) proposed studies to assess how the performance of a team using self-conscious robots can change according to different levels of accuracy of prediction of the robots.

\section{CONCLUSION}

This article sought to understand some specificities inherent to collaborative robotics in the context of i4.0 and to identify central themes that represent opportunities for future research on COBOTs. It was observed that the state-of-the-art on the topic is oriented towards improving the productivity and efficiency of industrial activities, as well as the quality of work since the interaction between man-machine reduces ergonomic tension. However, there are caveats in its applicability since the aspects inherent to the implementation of COBOTs require an adapted physical structure, and the high cost of this implementation, in addition to requiring trained personnel for operationalization.

The second research question allowed identifying six opportunities for future research covering the themes: safety, morale, standardization, comparative analysis of performance between different types of robots, integration with the technologies of i4.0, and technologies applied to human-robot interaction. A relevant consideration in this paper concerns the five most discussed topics, which represent $77.38 \%$ of the publications and deal with issues related to the work environment's health and safety, applications in assembly lines, and technical aspects of COBOTs. These issues can be considered an open window for potential research on industrial robotics. Some limitation exists in our approach. First, this study did not cover articles from other databases and technical literature on COBOTs. Next, we took a generalized landscape perspective on the application of robotics in the manufacturing process. For guidance and prescriptions on this topic, further studies involving field research and case studies will be needed. Finally, the issues and specificities addressed in this paper may stimulate new studies and projects to implement COBOTs on the production management agenda. 


\section{REFERENCES}

Aaltonen, I., Salmi, T., and Marstio, I. (2018). Refining levels of collaboration to support the design and evaluation of human-robot interaction in the manufacturing industry. Proceeded CIRP, 72, 93-98. https://doi.org/10.1016/j.procir.2018.03.214

Andersson, L.A., and Nygards, J. (2008). C-SAM: Multi-robot SLAM using square root information smoothing. In Robotics and Automation, ICRA 2008. IEEE International Conference. 2798-2805. http://doi.org/10.1109/ROBOT.2008.4543634

Bahrin, M.A.K., Othman, M.F., Azli, N.H.N., and Talib, M. F. (2016). Industry 4.0: A review on industrial automation and robotic. Jurnal Teknologi, 78, 6-13.

Barattini, P., Morand, C., and Robertson, N.M. (2012). A proposed gesture set for the control of industrial collaborative robots. In RO-MAN, IEEE, 132-137. http://doi.org/10.1109/ROMAN.2012.6343743

Bayram, B., and İnce, G. (2018). Advances in Robotics in the Era of Industry 4.0. In Industry 4.0: Managing The Digital Transformation, 187-200. Springer, Cham.

Bloem, J., Van Doorn, M., Duivestein, S., Excoffier, D., Maas, R., and Van Ommeren, E. (2014). The Fourth Industrial Revolution: Things to tighten the link between IT and OT. Sogeti VINT2014.

Bogue, R. (2017). Robots that interact with humans: a review of safety technologies and standards. Industrial Robot: An International Journal, 44(4), 395-400. https://doi.org/10.1108/IR-04-2017-0070

Briody, B. (2013). The Robot Reality: Service Jobs are Next to Go [Online]. Fiscal Times. Available at: http://www.thefiscaltimes.com/Articles/2013/03/26/The-Robot-RealityService-Jobs-are-Next-to-Go [Accessed: 4 April 2015].

Brizzi, P., Conzon, D., Khaleel, H., Tomasi, R., Pastrone, C., Spirito, A.M., and Cultrona, P. (2013) Bringing the Internet of Things along the manufacturing line: A case study in controlling industrial robot and monitoring energy consumption remotely. In Emerging Technologies \& Factory Automation (ETFA), IEEE 18th Conference, 1-8.

Cremer, S., Mastromoro, L. and Popa, D.O. (2016). On the performance of the Baxter research robot. In Assembly and Manufacturing (ISAM), 2016 IEEE International Symposium, 106-111.

Djuric, A., and Urbanic, R.J. (2018). Using collaborative robots to assist with travel path development for material deposition based additive manufacturing processes. Computer-Aided Design and Applications, 15(4), 542-555. https://doi.org/10.1080/16864360.2017.1419642

Dragan, A.D., Lee, K.C., and Srinivasa, S.S. (2013). Legibility and predictability of robot motion. In Proceedings of the 8th ACM / IEEE international conference on Human-robot interaction, 301-308.

Gunasekaran, A. (1999). Management policies of computer-integrated manufacturing/robotics. Handbook of Industrial Robotics, 473-494.

Hedelind, M., and Jackson, M. (2011). How to improve the use of industrial robots in lean manufacturing systems. Journal of Manufacturing Technology Management, 22(7), 891-905. https://doi.org/10.1108/17410381111160951

International Organization for Standardization - ISO (2016). Robots and Robotic Devices Collaborative Robots, document ISO / TS 15066.

Krüger, J., Bernhardt, R., Surdilovic, D., and Spur, G. (2006). Intelligent assist systems for flexible assembly. CIRP Annals-Manufacturing Technology, 55(1), 29-32. http://doi.org/10.1016/S0007-8506(07)60359-X

Kull, H. (2015). Mass customization: Opportunities, methods, and challenges for manufacturers. Apress.

Lasota, P.A., and SHAH, J.A. (2015). Analyzing the effects of human-aware motion planning on close-proximity human - robot collaboration. Human Factors, 57(1), 21-33. https://doi.org/10.1177\%2F0018720814565188

Matthias, B., Kock, S., Jerregard, H., Kallman, M., Lundberg, I., and Mellander, R. (2011). Safety of collaborative industrial robots: Certification possibilities for a collaborative assembly robot concept. In Assembly and Manufacturing (ISAM), 2011 IEEE International Symposium, 1-6. http://doi.org/10.1109/ISAM.2011.5942307

Maurice, P., Schlehuber, P., Padois, V., Measson, Y., and Bidaud, P. (2014). Automatic selection of ergonomie indicators for the design of collaborative robots: A virtual-human in the loop approach. In Humanoid Robots (Humanoids). 14th IEEE-RAS International Conference, 801-808. http://doi.org/10.1109/HUMANOIDS.2014.7041455

Merchán-Cruz, E.A., and Morris, A.S. (2006). Fuzzy-GA-based trajectory planner for robot manipulators sharing a common workspace. IEEE Transactions on Robotics, 22(4), 613-624. http://doi.org/10.1109/TRO.2006.878789

Murphy, R., Murphy, R.R., and Arkin, R.C. (2000). Introduction to AI robotics. MIT press. 
Peshkin, M.A., Colgate, J.E., Wannasuphoprasit, W., Moore, C.A., Gillespie, R.B., and Akella, P. (2001). Cobot architecture. IEEE Transactions on Robotics and Automation, 17(4), 377-390. http://doi.org/10.1109/70.954751

Pimenta, M.L. (2019). Cross-functional integration in product development processes in the era of industry 4.0. Production and Development Magazine. 5. https://doi.org/10.32358/rpd.2019.v5.350

Robla-Gómez, S., Becerra, V.M., Llata, J. R., Gonzalez-Sarabia, E., Torre-Ferrero, C., and Perez-Oria, J. (2017). Working together: a review on safe human-robot collaboration in industrial environments. IEEE Access, 5, 2675426773. http://doi.org/10.1109/ACCESS.2017.2773127

Romero, D., Stahre, J., Wuest, T., Noran, O., Bernus, P., Fast-Berglund, Å., and Gorecky, D. (2016). Towards an operator 4.0 typology: a human-centric perspective on the fourth industrial revolution technologies. In proceedings of the international conference on computers and industrial engineering (CIE46), Tianjin, China, 29-31.

Roy, N., and Dudek, G. (2001). Collaborative robot exploration and rendezvous: Algorithms, performance bounds and observations. Autonomous Robots, 11(2), 117-136. https://doi.org/10.1023/A:1011219024159

Rozo, L., Calinon, S., Caldwell, D.G., Jimenez, P., and Torras, C. (2016). Learning physical collaborative robot behaviors from human demonstrations. IEEE Transactions on Robotics, 32(3), 513-527. http://doi.org/10.1109/TRO.2016.2540623

Rüßmann, M., Lorenz, M., Gerbert, P., Waldner, M., Justus, J., Engel, P., and Harnisch, M. (2015). Industry 4.0: The future of productivity and growth in manufacturing industries. Boston Consulting Group, 9(1), 54-89.

Sapietová, A., Saga, M., Kuric, I., and Václav, Š. (2018). Application of optimization algorithms for robot systems designing. International journal of advanced robotic systems, 15(1), $1-10$. https://doi.org/10.1177\%2F1729881417754152

Schwab, K. (2017). The fourth industrial revolution. New York: Crown Business.

Silva, G.G.M.P.D., Tubino, D.F., and Seibel, S. (2015). Linhas de montagem: revisão da literatura e oportunidades para pesquisas futuras. Production, 25(1), 170-182. http://dx.doi.org/10.1590/S0103-65132014005000001

Slack, N., Chambers, S., Harland, C., Harrison, A., and Johnston, R.A.D.P. (1999). Administração da produção e operações. São Paulo: Editora Atlas.

Šurdilović, D., Bernhardt, R., and Zhang, L. (2003). New intelligent power-assist systems based on differential transmission. Robotica, 21(3), 295-302. http://doi.org/10.1017 / S0263574702004800

Tamás, P., Illés, B., and Dobos, P. (2016). Waste reduction possibilities for manufacturing systems in the industry 4.0. 20th Innovative Manufacturing Engineering and Energy Conference - IManEE.

Thomopoulos, N.T. (2014). Assembly line planning and control. Springer International Publishing.

Virk, G.S, Moon, S., and Gelin, R. (2008). ISO standards for service robots. In Advances in Mobile Robotics, 133-138. https://doi.org/10.1142/9789812835772_0016

Wang, L.; and Wang, G. (2016). Big data in cyber-physical systems, digital manufacturing and industry 4.0. International Journal of Engineering and Manufacturing (IJEM), 6(4), $1-8, \quad 2016$. https://doi.org/10.5815/IJEM.2016.04.01

Webster, J., and Watson, R. (2002). Analyzing the past to prepare for the future: Writing a literature review. MIS quarterly. 26(2), xii-xxiii.

Weiss, A., Huber, A., Minichberger, J., and Ikeda, M. (2016). First application of robot teaching in an existing industry 4.0 environment: Does it really work?. Societies, 6(3), 20. https://doi.org/10.3390/soc6030020 


\section{DECLARATION OF CONTRIBUTIONS TO THE ARTICLE - CRediT}

\begin{tabular}{|c|c|c|c|c|c|}
\hline ROLE & Author1 & Author2 & Author3 & Author4 & Author5 \\
\hline $\begin{array}{l}\text { Conceptualization - Ideas; formulation or evolution of overarching research goals and } \\
\text { aims. }\end{array}$ & $\mathrm{X}$ & & & $\mathrm{X}$ & $\mathrm{X}$ \\
\hline \multicolumn{6}{|l|}{$\begin{array}{l}\text { Data curation - Management activities to annotate (produce metadata), scrub data and } \\
\text { maintain research data (including software code, where it is necessary for interpreting } \\
\text { the data itself) for initial use and later re-use. }\end{array}$} \\
\hline $\begin{array}{l}\text { Formal analysis - Application of statistical, mathematical, computational, or other } \\
\text { formal techniques to analyze or synthesize study data. }\end{array}$ & $\mathrm{X}$ & & & $\mathrm{X}$ & $\mathrm{X}$ \\
\hline \multicolumn{6}{|l|}{$\begin{array}{l}\text { Funding acquisition - Acquisition of the financial support for the project leading to } \\
\text { this publication. }\end{array}$} \\
\hline \multicolumn{6}{|l|}{$\begin{array}{l}\text { Investigation - Conducting a research and investigation process, specifically } \\
\text { performing the experiments, or data/evidence collection. }\end{array}$} \\
\hline Methodology - Development or design of methodology; creation of models. & & $\mathrm{X}$ & $\mathrm{X}$ & & \\
\hline $\begin{array}{l}\text { Project administration - Management and coordination responsibility for the research } \\
\text { activity planning and execution. }\end{array}$ & $X$ & $\mathrm{X}$ & $\mathrm{X}$ & & \\
\hline \multicolumn{6}{|l|}{$\begin{array}{l}\text { Resources - Provision of study materials, reagents, materials, patients, laboratory } \\
\text { samples, animals, instrumentation, computing resources, or other analysis tools. }\end{array}$} \\
\hline \multicolumn{6}{|l|}{$\begin{array}{l}\text { Software - Programming, software development; designing computer programs; } \\
\text { implementation of the computer code and supporting algorithms; testing of existing } \\
\text { code components. }\end{array}$} \\
\hline $\begin{array}{l}\text { Supervision - Oversight and leadership responsibility for the research activity } \\
\text { planning and execution, including mentorship external to the core team. }\end{array}$ & & $X$ & $\mathrm{X}$ & & \\
\hline \multicolumn{6}{|l|}{$\begin{array}{l}\text { Validation - Verification, whether as a part of the activity or separate, of the overall } \\
\text { replication/reproducibility of results/experiments and other research outputs. }\end{array}$} \\
\hline $\begin{array}{l}\text { Visualization - Preparation, creation and/or presentation of the published work, } \\
\text { specifically visualization/data presentation. }\end{array}$ & $\mathrm{X}$ & & & $\mathrm{X}$ & $\mathrm{X}$ \\
\hline $\begin{array}{l}\text { Writing - original draft - Preparation, creation and/or presentation of the published } \\
\text { work, specifically writing the initial draft (including substantive translation). }\end{array}$ & $\mathrm{X}$ & & & $\mathrm{X}$ & $X$ \\
\hline $\begin{array}{l}\text { Writing - review \& editing - Preparation, creation and/or presentation of the } \\
\text { published work by those from the original research group, specifically critical review, } \\
\text { commentary or revision - including pre- or post-publication stages. }\end{array}$ & $X$ & $X$ & $X$ & $X$ & $X$ \\
\hline
\end{tabular}

